\title{
Wina a niefortunność - o przeprosinach po polsku i japońsku
}

\section{Arkadiusz Jabłoński}

Uniwersytet im. Adama Mickiewicza w Poznaniu yaboo@amu.edu.pl

\section{Streszczenie}

Gatunki mowy moga służyć odmiennym funkcjom pragmatycznym w rozmaitych środowiskach komunikacyjnych. Niekiedy funkcje te ujawniaja zróżnicowania niezrozumiałe dla nierodzimych użytkowników języka i kultury. Stwierdzenie to pozostaje w szczególny sposób aktualne $w$ komunikacji międzykulturowej, na granicy środowisk kulturowych. Niniejszy artykut zawiera próbę schematycznej charakterystyki różnic między zastosowaniem gatunku mowy (procedury komunikacyjnej) przeprosin $w$ polskim i japońskim środowisku komunikacyjnym. Postulaty badawcze weryfikowano na konkretnych przykładach aktywności komunikacyjnej w środowisku międzykulturowym.

Słowa kluczowe: gatunki mowy, komunikacja międzykulturowa, przeprosiny, język polski, język japoński.

\section{Abstract}

Fault and Infelicity - Apologies in Polish and Japanese

Genres of speech may serve different pragmatic functions in various communication environments. In some cases these functions may reveal differences unintelligible for nonnative users of language and culture. This statement is especially valid in cross-cultural communication, on the verge of cultural environments. This paper brings an attempt at a schematic description of differences between the implementation of a speech genre (communication procedure) of apology in Polish and Japanese communication environments. Research postulates have been verified using actual examples of communication activity in a cross-cultural environment.

Keywords: genres of speech, cross-cultural communication, apologies, Polish, Japanese. 


\section{Wstęp. Nieporozumienia międzykulturowe}

Kontakt międzykulturowy rodzi nieuniknione problemy. Cecha konstruktywnego ich rozwiązywania odróżnia akty komunikacji międzykulturowej od zjawisk styczności kulturowej jako takiej. Potop szwedzki czy wydarzenia 11 września 2001 to niewątpliwie akty styczności kulturowej, które trudno jednak kwalifikować jako akty komunikacyjne. Podobnie akt komunikacyjny realizowany $\mathrm{w}$ sposób nieprawidłowy traci cechy komunikacji, tworząc problemy miast je rozwiązywać.

Problemy międzykulturowe mogą dotyczyć odbioru schematów kultury docelowej przez kulturowych intruzów na poziomie właściwości kodu. Skomplikowanie japońskich wykładników honoryfikatywnych skłania oto autorkę jednego z podręczników japońskiej „grzeczności” (keigo) do stwierdzenia, że zarzucenie honoryfikatywności (cokolwiek miałoby to oznaczać) równa się przyjściu na kolację w kostiumie kąpielowym (Niyekawa, 1991: 9). Tytuł odpowiedniego podrozdziału pracy brzmi: „Why use keigo?”, tak jakby możliwe było swobodne decydowanie o tym, czy użytkownik języka bierze pod uwagę zróżnicowania kontekstowe komunikatu, czy też posługuje się jakąś tajemniczą odmianą kodu, która jest w stanie je ignorować.

Także kompetencja w odniesieniu do tego samego kodu może mieć charakter stopniowalny. W polskim środowisku komunikacyjnym wybór między użyciem zaimka osobowego „zwykłego" (w terminach Browna i Gilmana, 1960: typu T) ty/wy a zaimka „wyszukanego" (wg Browna i Gilmana: typu V) pan//pani/państwo nie dotyczy „ugrzecznienia” wypowiedzi, ale wyznacza w istotnym sensie zakres dopuszczalnych strategii komunikacyjnych. Zdolność poczynienia wyboru w ramach tej opozycji (lub też uchylenia się od wyboru, co także jest możliwe) wpływa na jakość komunikowania się. (Młodzi) Polacy, którzy wstydzą się, kiedy tytułowani są przy użyciu zaimka typu V lub wręcz otwarcie proszą o jego zaniechanie, nie są gotowi do pełnienia pewnych ról społecznych. Umiejętności takie nabywane są w procesie socjalizacji. Możliwe, że niektórzy użytkownicy kodu nie nabędą ich nigdy.

\section{Prawidłowość wypowiedzi a tożsamość struktur}

Problemów komunikacyjnych nie sposób wyjaśnić w warunkach sztucznych. Sugito (2004) wskazuje, że udzielenie odpowiedzi na pytanie eksperymentatora o decyzję honoryfikatywną w danej sytuacji implikuje, iż sytuacja taka istnieje (chodzi dokładnie o sformułowanie przez japońskiego informatora pytania do „bardzo szanowanej osoby, zajmującej wyższą pozycję” o 
to, co osoba ta czyta, podczas gdy wysoce prawdopodobne jest, że pytanie takie nie pojawiłoby się wcale $\mathrm{w}$ japońskim środowisku komunikacyjnym). Czy językoznawstwo w sposób skuteczny podejmuje takie problemy z pragmatycznego punktu widzenia, nie poprzestając na semantyce?

Adekwatność wzorców dotyczy nie tylko problemów językowych, ale także schematów postępowania odzwierciedlających struktury ludzkiej wiedzy (Schank, Abelson 1977). Mają one umożliwiać rozpoznanie i rozumienie łańcuchów przyczynowych zachowań (tamże: 23 i nast.) oraz realizacji celów, niekoniecznie deklarowanych otwarcie. Jeśli nawet realizację celów ujmować w terminach skryptów (tamże: 36 i nast.), dla kulturowego intruza wcale nie muszą być oczywiste interpretacje nawet pozornie prostych komunikatów, takich jak poniższy: "John went to a restaurant. He ordered a hamburger. It was cold when the waitress brought it. He left her a very small tip." (tamże: 45)

Odbiorca tekstu rozpozna i zinterpretuje tylko te jego elementy, które sam uzna za istotne i znaczące. W pewnych środowiskach połączenie elementu 'restauracja' z elementami 'hamburger' czy 'napiwek' nie jest oczywiste. Inni użytkownicy mogą zastanawiać się, dlaczego wyżej pojawia się element waitress ('kelnerka'), uznając go za nacechowany wobec wersji 'kelner'.

Społeczność językowa funkcjonuje w oparciu o znajomość kodu i wzorców jego użycia (Hymes 1974: 51). Możliwa jest sytuacja, gdy kod jest użytkownikowi znany, ale w interpretacji przekazu nie sposób wykorzystać żadnego ze znanych wzorców.

\section{1. „Wyrażanie pragnień” a hierarchiczność}

Funkcjonowanie w heterogenicznym kulturowo środowisku może być utrudnione wobec braku metajęzyka umożliwiającego analityczny i obiektywny opis faktów komunikacyjnych. Próby stworzenia metajęzyka natrafiać mogą na przeszkody nie do przebycia w ujęciu ściśle semantycznym, w oderwaniu od pragmatyki komunikacyjnej. Goddard i Wierzbicka (2001) przeciwstawiają sobie japoński i amerykański skrypt „mówienia o tym, czego się pragnie”, stwierdzając, iż kultura japońska: ,jest szeroko znana z lakoniczności” (tamże) oraz że: „mocno zniechęca (...) do jasnego wyrażania życzeń czy pragnień” (tamże). Metajęzyk autorów wydaje się podlegać wpływowi ich natywnych punktów widzenia. Uznanie kultury japońskiej en gross za nacechowaną „lakonicznością” stwarza wrażenie, jakoby po japońsku rzeczywiście nie było możliwe, ,jasne” wyrażanie pragnień. W rzeczywistości możliwość wyrażania pragnień zależy od realizowanej w danej sekwencji roli wertykalnej. 
Uwaga autorów, że w kulturze japońskiej powiedzieć to, „,czego się pragnie” można tylko w odniesieniu do dobrych znajomych i rodziny (tamże) ujawnia horyzontalną interpretację stosunków międzyludzkich opartych na znajomości i zażyłości. W tekście co prawda występuje wzmianka o hierarchiczności społeczeństwa japońskiego (tamże), brak jednak opisu wertykalnej, niesymetrycznej hierarchii rang obowiązującej $\mathrm{w}$ japońskim środowisku komunikacyjnym.

Hierarchię taką Nakane (1970: 30) opisuje następująco: „ktoś nieświadom swej relatywnej rangi nie jest w stanie nic powiedzieć ani nawet zająć miejsca przy stole czy spożyć posiłku.” stwierdza także: „W zasobie norm japońskiej etykiety znajdujemy tylko dwa podstawowe wzorce zachowań: odpowiedni wobec osoby $<<$ wyższej $>>$ w hierarchii i wobec osoby o randze $<<$ niższej>>" (tamże).

\subsection{Przeprosiny ,magiczne"}

Łysakowski (2006) opisuje frazę "Przepraszam” jako „magiczną”, podkreślając odpowiedzialność wypowiadającej ją osoby za naruszenie norm społecznych, poczucie winy oraz okazanie skruchy. Zauważa on różnicę między przeprosinami i wiadomościami podobnymi do przeprosin, lecz niosącymi inne znaczenie. Czy jednak klasyfikacja ta nie na tworzy bytów ockhamowskich? „Magiczność” trudno opisać w kategoriach naukowych. Ponadto cel realizacji sekwencji przeprosin pozostaje wysoce przewidywalny i niekoniecznie dotyczy poczucia winy czy wyrażenia skruchy. Nawet jeśli przeprosiny z aktów skruchy rzeczywiście się wywodzą, ich zastosowanie przynajmniej w pewnych środowiskach komunikacyjnych wydaje się służyć raczej rozwiązaniu lub zapobieżeniu zawczasu sytuacjom problemowym w trakcie interakcji. Te cechy przeprosin zostaną dalej omówione w odniesieniu do polsko-japońskiej interakcji międzykulturowej.

\subsection{Schematy}

Oto schematyczne zestawienie wymogów środowisk komunikacyjnych PL i JP dotyczących rozpoznania „równości” partnerów (polska hierarchia horyzontalna) bądź rang wyższej (senior) i niższej (junior) (japońska hierarchia wertykalna).

KONTEKST PL: Uczestnicy konwersacji mają równe prawa w tym sensie, że inicjacja wielu sekwencji nie narzuca definicji rang w terminach wertykalnych. Partnerzy odwołują się do pojęcia prawdy obiektywnej i dostępnej obu stronom (stąd stosunkowo nieliczne ograniczenia w „wyrażaniu pragnień”). Przepraszający stawia się w pozycji słabszej. Można 
nawet stwierdzić, że przeprosin się unika, co odzwierciedlają w pewnym stopniu następujące wypowiedzi charakterystyczne dla polskiego środowiska komunikacyjnego:

„To jego wina, więc niech on przeprasza”.

„Już pana przeprosiłem”.

KONTEKST JP: Uczestnicy interakcji nie mają równych praw - inicjacja wielu sekwencji wymaga zawczasu subiektywnej definicji rang wertykalnych. Uczestnik wyższy rangą może pozwolić sobie na więcej (nie obowiązuje go także wymóg „lakoniczności”). Uczestnik niższy rangą zobowiązany jest do nadzorowania parametrów komunikacyjnych i dostosowania się do partnera wyższego rangą. Przeprosiny stanowią doskonały ku temu środek, niezależnie od pojęcia winy. Ujęcie to można sparafrazować następująco:

„Nie chodzi o to, kto jest winien, ale o to, czy spójność sytuacji wymaga przeprosin”.

„Nigdy nie zaszkodzi przeprosić seniora na wszelki wypadek”.

W świetle powyższego nie powinna zaskakiwać uwaga Umedy (1997) o „trudnościach w egzekwowaniu przeprosin" od Polaków. Nie chodzi tu o szczerość przeprosin czy o poczucie winy. Rzecz raczej w trudności realizacji przez polskiego partnera komunikacyjnego roli wertykalnego juniora.

\subsection{Klincze proceduralne oraz ich rozwiązywanie}

Unikanie roli wertykalnego juniora przez stronę polską w interakcji międzykulturowej PL-JP może prowadzić do nierozwiązywalnych sytuacji problematycznych. Oto relacja polskiej thumaczki uczestniczącej w polsko-japońskim projekcie thumaczeniowym w Japonii:

W zeszłym tygodniu byłam dość mocno przeziębiona, ale postanowiłam (...) nie zostawiać mojej grupy bez tłumacza. Tak się złożyło, że w tym stanie (...) przyszło mi tłumaczyć rozmowę podopiecznych z panem X. $\mathrm{W}$ trakcie tej rozmowy poprosiłam pana $\mathrm{X}$. o powtórzenie jakiejś kwestii, tłumacząc, że jestem przeziębiona i niezbyt dobrze słyszę. Żniwa tej niefortunnej wypowiedzi miałam nieprzyjemność odebrać dzisiaj za pośrednictwem tutejszego opiekuna, pana Y. Poinformowano mnie, że zastąpi mnie ktoś z nowej grupy tłumaczy (...), a mnie zostanie zlecona praca przy tłumaczeniach pisemnych w biurze. Choć tłumaczyłam, że to była sytuacja wyjątkowa, że byłam chora i rzeczywiście nie słyszałam, ale teraz jest wszystko w najlepszym porządku, choć mówiłam, że będę najlepiej jednak zorientowana w szkoleniu, skoro uczestniczyłam w nim od początku, i że nie chce zmieniać teraz swojego stanowiska na tłumacza pisemnego, dostałam odpowiedź w stylu japońskim, iż zobaczymy, jak sobie nowa osoba będzie dawać radę, ewentualnie obietnicę ponownego przemyślenia kwestii. Jak pewnie Pan zauważył, logiki w tym postanowieniu żadnej nie ma, można jedynie wyciągnąć wnioski, że nie warto zostawać w pracy będąc przeziębionym (XX, 28.02.2008, 12:21). 
Odpowiedź na tak sformułowany list wymaga rozpoznania realiów japońskiego środowiska komunikacyjnego (niższej rangi wertykalnej tłumaczki oraz wyższej rangi przedstawiciela klienta), lecz nie musi być wcale oczywista ani łatwa w odbiorze:

„To rzeczywiście bardzo nieprzyjemna sytuacja. (...) Takie rzeczy się zdarzają i trzeba je jakoś rozwiązywać. Po japońsku trzeba by na pani miejscu przy najbliższej okazji przeprosić za uczynione shitsurei, (nieuprzejmość - A. J.) licząc na to, że partner także się zreflektuje i pozostawiając decyzję jemu. Nie ma co thumaczyć tej sytuacji, gdyż możliwe, że pan X. sam już o tym nie pamięta, a na pewno nie chce do tego wracać.

Po polsku trzeba by poczekać aż emocje opadną i śledzić, jak sprawa się rozwinie. Dla mnie osobiście sytuacja ta nie zmienia niczego w stosunku do pani i nie sadzę, by klient chciał przysporzyć pani kłopotów. Myślę, że można zastosować jednocześnie obie metody - polską i japońską" (AJ, 28.02.2008, 12:53).

Inny przykład interakcji polsko-japońskiej dotyczy niepochlebnej wypowiedzi o zdolnościach jednego z członków polskiej załogi przedsiębiorstwa, jaką miał wygłosić japoński przełożony. Była to reakcja na prośbę o zwolnienie z pracy z powodu wypadku, jakiemu podwładny uległ w trakcie jazdy konnej w dniu wolnym od pracy. W realiach polskich można w takiej sytuacji oczekiwać właściwie wyłącznie zorientowanej horyzontalnie (adresowanej do „bliźniego”) sekwencji wyrażenia współczucia. Japoński przełożony (senior) mógł otwarcie sugerować niemoc intelektualną podwładnego (juniora), który postąpił nieodpowiedzialnie $\mathrm{w}$ życiu prywatnym, mimo ważnych funkcji pełnionych przezeń $\mathrm{w}$ zakładzie produkcyjnym. Akceptowalnym rozwiązaniem takiej sytuacji byłoby zastosowanie przez juniora przeprosin, co pozwoliłoby seniorowi uzyskać całkowicie należną mu pewność, że relacja między podwładnym a przełożonym jest obustronnie rozpoznawana jako tak samo istotna.

Niewłaściwe rozpoznanie rang komunikacyjnych prowadzić może do komunikacyjnego klinczu i wystąpienia transakcji niedokończonych. Odwołanie się ,winy” partnera lub do polskiej „logiki” konwersacyjnej na niewiele może się tu przydać. Wdrożenie sekwencji przeprosin przez osobę niższą rangą, nawet jeśli niełatwe z polskiego punktu widzenia, może być jedynym sposobem uratowania sytuacji komunikacyjnej. 


\section{Wnioski}

Wertykalne (oparte na schemacie rang niesymetrycznych) zorientowanie elementów kontekstu w japońskim środowisku komunikacyjnym sprawia, że przeprosiny nie muszą być „szczere”. Istnieje zarazem wymóg zastosowania $\mathrm{w}$ określonych sytuacjach przeprosin $\mathrm{w}$ sposób niepozostawiający wątpliwości co do tego, że komunikacyjna niefortunność jest rozpoznawana.

Przeprosiny służą wyjaśnianiu w sposób przewidywalny sytuacji nieprzewidywalnych. Nie muszą one zakładać „winy” przepraszającego.

Mój japoński znajomy mawiał, że od rozpatrywania winy jest policja i sąd. Skoro doświadczenie uczy, że niefortunności komunikacyjne mogą się zdarzać i zdarzają się istotnie, w środowisku międzykulturowym należałoby także skupić się raczej na rozwiązywaniu nieprawidłowości, nie na ich roztrząsaniu. Nastawienie takie nie jest bynajmniej zupełnie nieznane w Polsce, nawet jeśli nie zawsze można je zaobserwować w warunkach rzeczywistych. Oto porada z przedwojennego podręcznika dobrych manier: „Uprzejmość nic nie kosztuje (...). Czy (...) może grać rolę częstsze użycie słówka <<przepraszam>>?” (Vauban, Kurcewicz 1935: 17).

Polska „uprzejmość” ma zarazem jednak charakter symetryczny. W realiach japońskich cytat powyższy ma zastosowanie wyłącznie do roli wertykalnego juniora.

\section{Źródło}

Tekst ten został po raz pierwszy opublikowany w 2010 roku w tomie Stowo $w$ dialogu międzykulturowym pod redakcją Władysława Chłopickiego i Marii Jodłowiec, Język a komunikacja 25. Kraków: Tertium; 143-150.

\section{Bibliografia}

(XX, AJ) Własne archiwum poczty elektronicznej autora.

Brown, Roger, W. Gilman Albert (1960) "The Pronouns of Power and Solidarity.” [W:] Thomas, A. Sebeok (red.) Style and Language. Cambridge: MIT; 253-276 (przedruk W: Pier P. Giglioli (red.) Language and Social Context. (1972). Middlesex, Baltimore: Penguin; 252-281). 
Goddard, Cliff, Anna Wierzbicka (2001) „Język, kultura i znaczenie: semantyka międzykulturowa". [W:] Elżbieta Tabakowska (red.), Kognitywne podstawy języka $i$ językoznawstwa. [Cognitive Exploration of Language and Linguistics. Brussels]. (thum.) Towarzystwo Autorów i Wydawców Prac Naukowych Universitas. Kraków: TAiWPN Universitas; 175-202.

Hymes, Dell (1974) Foundations in Sociolinguistics. An Ethnographic Approach. Philadelphia: University of Pennsylvania Press.

Łysakowski, Tomasz (2006) „Psychologia przepraszania”. [W:] Małgorzata Marcjanik (red.) Retoryka codzienności. Zwyczaje językowe współczesnych Polaków. Warszawa: Trio; 239-259.

Nakane, Chie (1970) Japanese Society. Berkeley, Los Angeles: University of California Press.

Niyekawa, Agnes, M. (1991) Minimum Essential Politeness. Tokyo, New York: Kodansha International.

Schank, Roger C., Robert P. Abelson (1977) Scripts, Plans, Goals and Understanding. Hillsdale, New Jersey: Lawrence Erlbaum Associates.

Sugito, Seiju (2004) „Kei’i hyōgen kōdō ni tsuite no kihan ishiki o mergutte (standardowa ocena zachowań dotyczących wyrażania szacunku)". Taigū komyunikēshon 2; 66-80.

Umeda, Yoshiho J. (1997) Na styku kultury polskiej i japońskiej (niepublikowane notatki z odczytów).

Vauban, Maria, Michał Kurcewicz (1935) Podstawy życia towarzyskiego. Warszawa: Wyd. M. Arcta. 